\title{
The pore size of polycaprolactone scaffolds has limited influence on bone regeneration in an in vivo model
}

\author{
Sara M. Mantila Roosa, ${ }_{1}^{1}$ Jessica M. Kemppainen, ${ }^{1}$ Erin N. Moffitt, ${ }^{1}$ Paul H. Krebsbach, ${ }^{1,2}$ \\ Scott J. Hollister ${ }^{1,3,4}$ \\ ${ }^{1}$ Department of Biomedical Engineering, University of Michigan, Ann Arbor, Michigan 48109-2099 \\ ${ }^{2}$ Department of Biologic and Material Sciences, School of Dentistry, University of Michigan, Ann Arbor, \\ Michigan 48109-1078 \\ ${ }^{3}$ Department of Mechanical Engineering, University of Michigan, Ann Arbor, Michigan 48109-2125 \\ ${ }^{4}$ Department of Surgery, University of Michigan, Ann Arbor, Michigan 48109-0329
}

Received 7 April 2008; revised 8 October 2008; accepted 31 October 2008

Published online 2 February 2009 in Wiley InterScience (www.interscience.wiley.com). DOI: 10.1002/jbm.a.32381

\begin{abstract}
Bone tissue engineering scaffolds should be designed to optimize mass transport, cell migration, and mechanical integrity to facilitate and enhance new bone growth. Although many scaffold parameters could be modified to fulfill these requirements, pore size is an important scaffold characteristic that can be rigorously controlled with indirect solid freeform fabrication. We explored the effect of pore size on bone regeneration and scaffold mechanical properties using polycaprolactone (PCL) scaffolds designed with interconnected, cylindrical orthogonal pores. Three scaffold designs with unique microarchitectures were fabricated, having pore sizes of 350,550 , or $800 \mu \mathrm{m}$. Bone morphogenetic protein-7 transduced human gingival fibroblasts were suspended in fibrin gel, seeded into scaffolds, and implanted subcutaneously in immuno-compromised mice for 4 or 8 weeks. We found that (1) modulus and peak stress
\end{abstract}

of the scaffold/bone constructs depended on pore size and porosity at 4 weeks but not at 8 weeks, (2) bone growth inside pores depended on pore size at 4 weeks but not at 8 weeks, and (3) the length of implantation time had a limited effect on scaffold/bone construct properties. In conclusion, pore sizes between 350 and $800 \mu \mathrm{m}$ play a limited role in bone regeneration in this tissue engineering model. Therefore, it may be advantageous to explore the effects of other scaffold structural properties, such as pore shape, pore interconnectivity, or scaffold permeability, on bone regeneration when designing PCL scaffolds for bone tissue engineering. (C) 2009 Wiley Periodicals, Inc. J Biomed Mater Res 92A: 359-368, 2010

Key words: pore size; bone tissue engineering; micro-computed tomography; polycaprolactone; scaffold

\section{INTRODUCTION}

Tissue engineering scaffolds have been used to support regeneration of many tissue types, such as bone, cartilage, vasculature, ligament, nerve, and skin. ${ }^{1-6}$ Scaffold properties vary from tissue to tissue, as each has unique mechanical and biochemical properties. A highly porous scaffold with an interconnected pore network is necessary to mediate nutrient and waste diffusion and to ultimately allow connected tissue growth. ${ }^{7,8}$ The scaffold design should also incorporate a microarchitecture that yields an adequate amount of mechanical strength to carry

Correspondence to: S. J. Hollister, 1109 Gerstacker Bldg., 2200 Bonisteel Blvd., Ann Arbor, Michigan 48109-2099; e-mail: scottho@umich.edu

Contract grant sponsor: NIH (Bioengineering Research Partnership); contract grant numbers: DE 13608, AR R01 053379

(C) 2009 Wiley Periodicals, Inc. load at the implantation site until new, load-bearing tissue is formed. ${ }^{7}$ Scaffold parameters may be varied to meet these requirements. In addition, scaffolds must be biocompatible, osteoconductive, and/or osteoinductive. Osteoconductive scaffolds facilitate cell attachment, proliferation, and differentiation. ${ }^{7,8}$ Scaffolds with osteoinductive properties enhance new tissue growth, for example, by delivery of biofactors. ${ }^{7}$

The pore size of a tissue engineering scaffold is an important parameter that affects the quantity and characteristics of new tissue formation. ${ }^{9}$ An optimal pore size for bone tissue engineering scaffolds is not well defined. Pore sizes of $10-2250 \mu \mathrm{m}$ have been used in bone tissue engineering scaffolds resulting in varying degrees of tissue in-growth. ${ }^{10-15,16}$ Pore sizes between 100 and $400 \mu \mathrm{m}$ are proposed as optimal for osteoconduction, ${ }^{17}$ and pore sizes greater than $300 \mu \mathrm{m}$ are recommended to enhance bone formation via vascularization. ${ }^{9}$ Pore sizes smaller than $100 \mu \mathrm{m}$ may not be sufficient in terms of mass transport and cell migration and may induce endochondral carti- 
lage formation before osteogenesis occurs. ${ }^{9}$ Larger pore sizes may result in excessive void space and compromise the mechanical properties of the scaffold; however, larger pore sizes are favorable for capillary formation, which leads to direct osteogenesis. ${ }^{9}$ Therefore, the scaffold pore size must be small enough to ensure mechanical integrity, but large enough to fulfill the nutrient and waste diffusion needs of the tissue. Along with pore size, many other scaffold characteristics and experimental design variables are also important in new tissue formation. These include porosity, permeability, pore interconnectivity, pore shape, mechanical properties, biomaterial, fabrication method, implant location, animal model, and use of cells and biofactors. ${ }^{7,8,10-12,17-19}$

Polycaprolactone (PCL) is a biocompatible, semicrystalline, slowly-degrading polymer used in several tissue engineering applications including bone ${ }^{7,8,12,15,20-23}$ and cartilage. ${ }^{24-27}$ Although PCL is not osteoconductive, it can be modified to increase osteoconductive and osteoinductive potential. For example, a PCL scaffold may be manufactured with growth factors and/or cells attached to the scaffold surface, or transduced cells and/ or growth factors may be seeded into the scaffold before implantation. $7,11,12,18-20$

We previously demonstrated bone tissue ingrowth on PCL and polypropylene fumarate/ $\beta$-tricalcium phosphate (PPF/ $\beta$-TCP) scaffolds with pore sizes of $1.75-2.25 \mathrm{~mm}^{12}$ and 300 or $800 \mu \mathrm{m}^{19}$ respectively in a subcutaneous mouse model. The objective of this study was to evaluate the effect of PCL scaffold pore sizes, between 350 and $800 \mu \mathrm{m}$, on bone regeneration and scaffold mechanical properties in the same tissue engineering model.

\section{MATERIALS AND METHODS}

\section{Scaffold design}

Scaffolds with interconnected, cylindrical orthogonal pores were designed using custom Interactive Data Language ${ }^{\mathrm{TM}}$ programs (IDL; Research Systems, Boulder, $\mathrm{CO}$ ). Three PCL scaffold designs were investigated in this study. First, we designed scaffolds for subcutaneous implantation into immuno-compromised mice (hereafter referred to as "subcutaneous" scaffolds). We designed three subcutaneous scaffolds with distinct microarchitectures: (1) pore size of $350 \mu \mathrm{m}$ and strut diameter of $350 \mu \mathrm{m}$, (2) pore size of $550 \mu \mathrm{m}$ and strut diameter of $600 \mu \mathrm{m}$, and (3) pore size of $800 \mu \mathrm{m}$ and strut diameter of $900 \mu \mathrm{m}$. The global subcutaneous scaffold shape was cylindrical (5 $\mathrm{mm}$ in diameter and $3 \mathrm{~mm}$ in height) and identical for each scaffold. Figure 1 shows $\mu \mathrm{CT}$ renderings of the three fabricated subcutaneous PCL scaffold designs.

Second, we designed PCL scaffolds to test bulk mechanical properties of the three subcutaneous scaffold designs (hereafter referred to as "mechanical testing" scaffolds).
Mechanical testing scaffolds had the same microarchitectures as subcutaneous scaffolds, but the global cylindrical shape of mechanical testing scaffolds was larger $(8 \mathrm{~mm}$ in diameter and $16 \mathrm{~mm}$ in height). The mechanical testing scaffolds satisfied the 2:1 aspect ratio requirement of the ASTM compression testing standard for rigid plastics (ASTM D695-02a).

Third, we designed solid PCL cylinders to test bulk mechanical properties of melt cast PCL. The global shape of the solid cylinders was cylindrical $(8 \mathrm{~mm}$ in diameter and $16 \mathrm{~mm}$ in height). The solid cylinders satisfied the 2:1 aspect ratio requirement of the ASTM compression testing standard for rigid plastics (ASTM D695-02a).

\section{Scaffold fabrication}

An indirect solid free-form fabrication (SFF) technique was utilized to build subcutaneous scaffolds in a layer-bylayer additive process. ${ }^{7,28}$ Molds were built on a 3D SolidScape (SolidScape, Merrimack, NH) printer and were made of a thermoplastic (melting temperature of $120^{\circ} \mathrm{C}$ ) and a waxy material comprised of natural and synthetic wax and fatty esters (melting temperature of $78^{\circ} \mathrm{C}$ ). The wax was melted in a vacuum oven (Fisher Scientific, Pittsburgh, PA) leaving intact thermoplastic molds. A hydroxyapatite (HA) slurry suspension (hydroxyapatite powder [Plasma Biotal, Tideswell, North Derbyshire, UK] used as-received, benzoyl peroxide [BPO], $N, N$-dimethyl $p$-toluidine [NMP], and acetone) was cast into thermoplastic molds at room temperature. HA molds were sintered at $1300^{\circ} \mathrm{C}$ with a $1 \mathrm{~h}$ dwell time and were furnace cooled.

Next, HA molds were cast into melted PCL. $\varepsilon$-PCL powder (CAPA 6501, Solvay Caprolactones, Warrington, Cheshire, UK; melting temperature of $60^{\circ} \mathrm{C}$, molecular weight of $50 \mathrm{kDa}$, and particle size distribution in the range of $10-100 \mu \mathrm{m}$ ) was packed into 6-mm diameter wells in a Teflon ${ }^{\mathbb{R}}$ casting mold. $\varepsilon$-PCL powder was melted in a vacuum oven which had been heated to $120^{\circ} \mathrm{C}$ and allowed to equilibrate. A $-20 \mathrm{inHg}$ vacuum was pulled immediately, maintained for $90 \mathrm{~min}$, and slowly released. HA molds were gently pushed into the melted PCL, and the entire construct was placed into the vacuum oven at $120^{\circ} \mathrm{C}$. A -20 inHg vacuum was pulled immediately, maintained for $30 \mathrm{~min}$, slowly released, and the constructs were allowed to cool to room temperature. After melt casting was complete, HA was removed using RDO Rapid Decalcifier (APEX Engineering Products, Plainfield, IL) leaving intact PCL scaffolds. PCL scaffolds were rinsed with water and $70 \%$ ethanol and were stored in $70 \%$ ethanol until cell seeding. Figure 2 describes a summary of the fabrication process used to create subcutaneous scaffolds.

Mechanical testing scaffolds were manufactured using the indirect SFF casting method described previously. However, a Teflon casting mold with 9-mm diameter wells was used to PCL melt cast mechanical testing scaffolds. Figure 2 describes a summary of the fabrication process used to create mechanical testing scaffolds.

Solid PCL cylinders were fabricated using the following method. $\varepsilon$-PCL powder was packed into 9-mm diameter wells in a Teflon casting mold. $\varepsilon$-PCL powder was melted in a vacuum oven which had been heated to $120^{\circ} \mathrm{C}$ and 


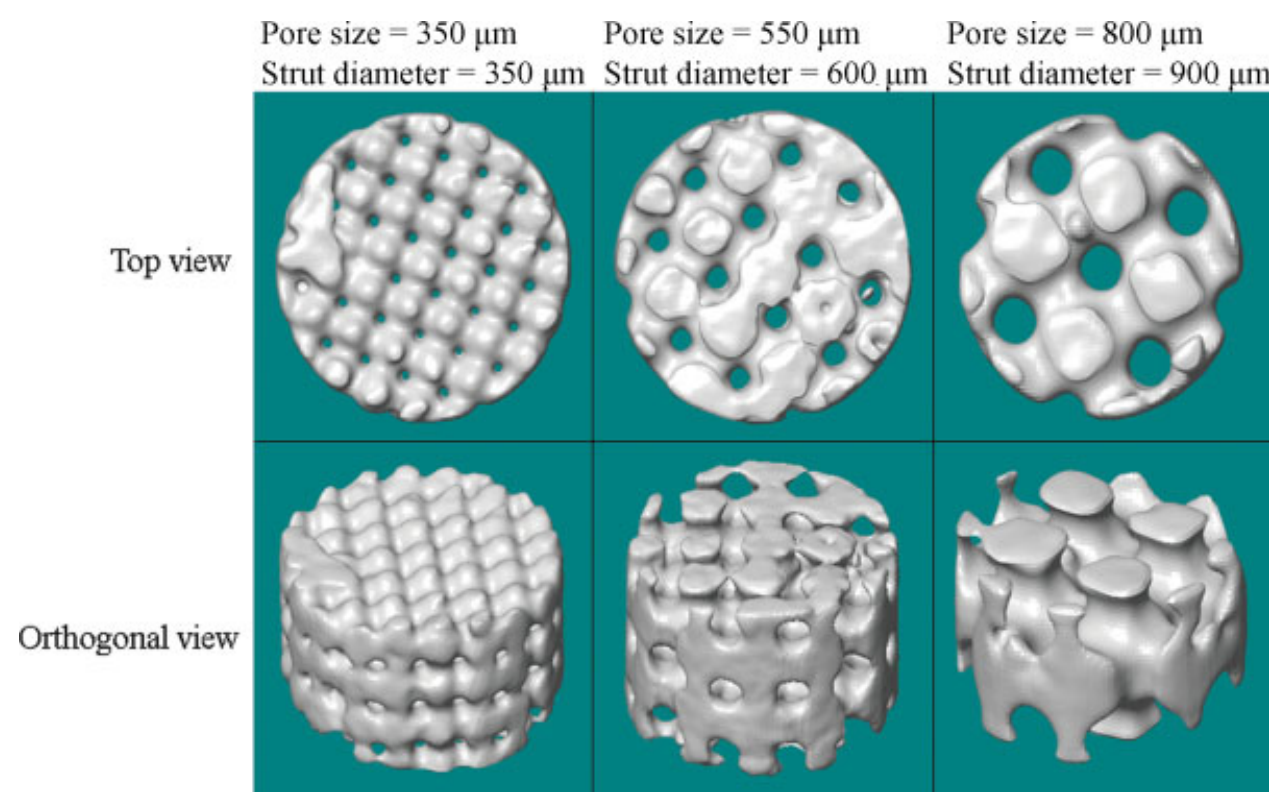

Figure 1. $\mu \mathrm{CT}$ renderings of subcutaneous scaffolds (prior to implantation) with three distinct microarchitectures. [Color figure can be viewed in the online issue, which is available at www.interscience.wiley.com.]

allowed to equilibrate. A vacuum of -20 inHg was pulled immediately, maintained for $75 \mathrm{~min}$, and slowly released. Teflon tubing ( $9 \mathrm{~mm}$ outer diameter, $8 \mathrm{~mm}$ inner diameter) was gently pushed into melted PCL to eliminate air bubbles on the exterior of the casting well. Melted PCL cooled to room temperature, and tubing was removed leaving solid PCL cylinders intact. Table I summarizes how subcutaneous scaffolds, mechanical testing scaffolds, and solid PCL cylinders were utilized.

\section{Presurgical subcutaneous scaffold assessment}

All subcutaneous scaffolds were scanned in air using an MS8X-130 high-resolution $\mu \mathrm{CT}$ scanner (GE Medical Systems, Toronto, CAN) with $28 \mu \mathrm{m}$ voxel resolution at $75 \mathrm{kV}$ and $75 \mathrm{~mA}$. GEMS Microview software (GE Medical Systems, Toronto, CAN) was used to verify scaffold pore size and calculate scaffold porosity. A threshold of -600 ADU defined the lower limit for PCL.

\section{Mechanical testing scaffold assessment}

Mechanical testing scaffolds were scanned with $\mu \mathrm{CT}$ and analyzed as described previously. Four wet scaffolds (soaked in water for $20 \mathrm{~min}$ ) were mechanically tested in compression for each microarchitecture. The specimens were tested to failure (or to a maximum of $40 \%$ strain) in the $\mathrm{z}$-direction between a rigid and flexible steel platen at a rate of $1 \mathrm{~mm} / \mathrm{min}$. TestWorks4 software (MTS Systems, $\mathrm{MN})$ was used to generate data.

\section{Solid PCL cylinder assessment}

Solid cylinders were scanned with $\mu \mathrm{CT}$ as described previously to ensure that no large air bubbles were present. Four wet cylinders (soaked in water for $20 \mathrm{~min}$ ) were mechanically tested in compression as described previously.

\section{Cell seeding and implantation}

Primary human gingival fibroblasts were prepared from explants of human surgical waste in accordance with the University of Michigan Institutional Review Board. Passage 11 human gingival fibroblasts were infected with AdCMV-BMP-7, a first generation recombinant adenovirus
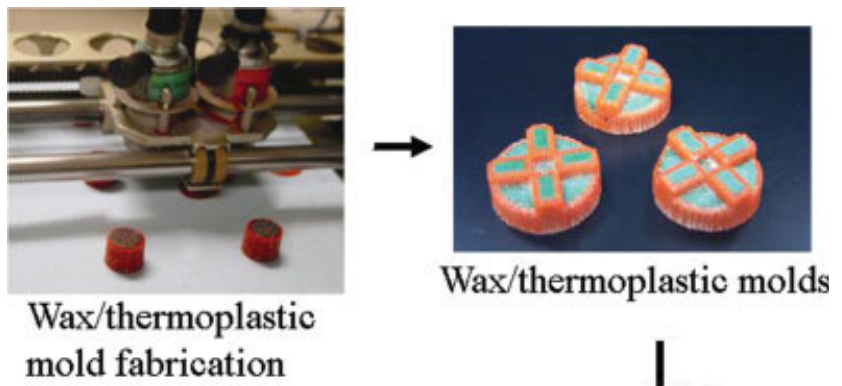

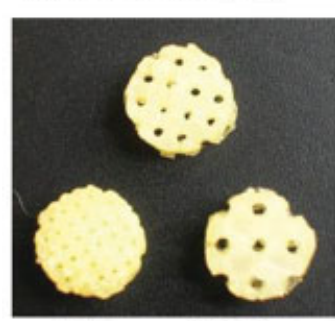

PCL scaffolds

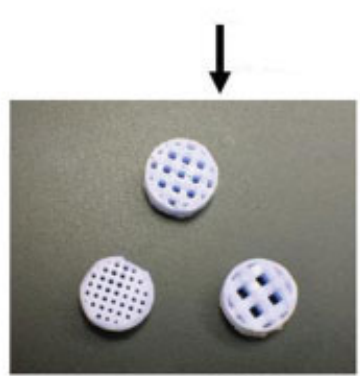

HA scaffolds
Figure 2. Summary of the indirect solid free-form fabrication (SFF) process used to create subcutaneous PCL scaffolds and mechanical testing PCL scaffolds. [Color figure can be viewed in the online issue, which is available at www.interscience.wiley.com.] 
TABLE I

Summary of All Fabricated Subcutaneous Scaffolds, Mechanical Testing Scaffolds, and Solid PCL Cylinders

\begin{tabular}{|c|c|c|c|}
\hline & Subcutaneous Scaffolds & $\begin{array}{l}\text { Mechanical Testing } \\
\text { Scaffolds }\end{array}$ & Solid PCL Cylinders \\
\hline Global dimensions & $\begin{array}{l}5 \mathrm{~mm} \text { diameter } \\
3 \mathrm{~mm} \text { height }\end{array}$ & $\begin{array}{l}8 \mathrm{~mm} \text { diameter } \\
16 \mathrm{~mm} \text { height }\end{array}$ & $\begin{array}{l}8 \mathrm{~mm} \text { diameter } \\
16 \mathrm{~mm} \text { height }\end{array}$ \\
\hline Microarchitectures & $\begin{array}{l}\text { Pore sizes of } 350 \mu \mathrm{m}, \\
550 \mu \mathrm{m} \text {, or } 800 \mu \mathrm{m} \\
\text { and respective strut } \\
\text { diameters of } 350 \mu \mathrm{m} \text {, } \\
600 \mu \mathrm{m} \text {, or } 900 \mu \mathrm{m}\end{array}$ & $\begin{array}{l}\text { Pore sizes of } 350 \mu \mathrm{m} \text {, } \\
550 \mu \mathrm{m} \text {, or } 800 \mu \mathrm{m} \\
\text { and respective strut } \\
\text { diameters of } 350 \\
\mu \mathrm{m}, 600 \mu \mathrm{m} \text {, or } 900 \\
\mu \mathrm{m}\end{array}$ & Solid PCL \\
\hline Total fabricated & $\begin{array}{l}n=66(n=22 \text { for } \\
\text { each microarchitecture) }\end{array}$ & $\begin{array}{c}n=12(n=4 \text { for each } \\
\text { microarchitecture })\end{array}$ & $n=4$ \\
\hline$\mu C \mathrm{~T}^{\mathrm{a}}$ & $\begin{array}{l}n=66(n=22 \text { for each } \\
\text { microarchitecture })\end{array}$ & $\begin{array}{c}n=12(n=4 \text { for each } \\
\text { microarchitecture })\end{array}$ & $n=4$ \\
\hline Implanted with cells (histology) & $\begin{array}{c}n=12(n=4 \text { for each } \\
\text { microarchitecture })\end{array}$ & Not implanted & Not implanted \\
\hline Implanted with cells (mechanical testing) & $\begin{array}{l}n=30(n=10 \text { for each } \\
\quad \text { microarchitecture })\end{array}$ & Not implanted & Not implanted \\
\hline $\begin{array}{l}\text { Implanted without cells (mechanical testing } \\
\text { and histology control) }\end{array}$ & $\begin{array}{c}n=24(n=8 \text { for each } \\
\text { microarchitecture })\end{array}$ & Not implanted & Not implanted \\
\hline Not implanted (bulk mechanical properties) & $\mathrm{N} / \mathrm{A}$ & $\begin{array}{c}n=12(n=4 \text { for each } \\
\text { microarchitecture })\end{array}$ & $n=4$ \\
\hline
\end{tabular}

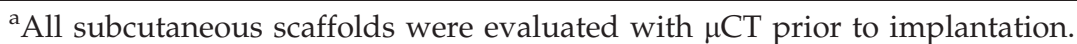

Mechanical testing scaffolds and solid PCL cylinders were not implanted.

construct expressing the murine BMP-7 gene under a cytomegalovirus (CMV) promoter. Cells were suspended in 5 $\mathrm{mg} / \mathrm{mL}$ fibrinogen. Sixty microliters of fibrinogen/cell suspension, containing $\sim 1.5$ million cells, was pipette into each of 42 subcutaneous scaffolds ( $n=14$ for each microarchitecture; hereafter referred to as "seeded" scaffolds). Three microliters of thrombin was added to each seeded scaffold to create fibrin gel and encapsulate cells. Sixty $\mu \mathrm{L}$ of fibrinogen suspension, containing no cells, was pipette into each of 24 subcutaneous scaffolds $(n=8$ for each microarchitecture; hereafter referred to as "control" scaffolds). Three microliters of thrombin was added to each control scaffold to create fibrin gel.

Seeded and control scaffolds were implanted subcutaneously into 5- to 8-week old immuno-compromised mice (N:NIH-bg-nu-xid, Charles River, Wilmington, MA). Animals were anesthetized with ketamine and xylazine (50 and $5 \mathrm{mg} / \mathrm{g}$, respectively). Four subcutaneous pockets were created dorsally (two on each side of the spine), one scaffold was implanted into each pocket, and surgical sites were closed with wound clips. Both seeded and control scaffolds were implanted into each animal, and scaffold implant location was randomized. Half of the scaffolds $(n$ $=21$ seeded scaffolds, $n=12$ control scaffolds) were evaluated after 4 weeks in vivo, and the remainder were evaluated after 8 weeks in vivo. NIH guidelines for the care and use of laboratory animals (NIH Publication no. 85-23 Rev. 1985) have been observed. Surgical procedures and protocols were in compliance with University Committee on Use and Care of Animals regulations.

\section{Seeded scaffold/tissue construct assessment}

After 4 or 8 weeks in vivo, mice were euthanized and all scaffolds were removed, placed into Z-Fix (Anatech, Battle
Creek, MI) overnight, and stored in 70\% ethanol. Seeded scaffolds were scanned in water in an MS8X-130 high-resolution $\mu \mathrm{CT}$ scanner to characterize newly formed tissue. Control scaffolds were scanned to verify that no mineralized tissue was formed inside the pores or around the scaffold exterior. GEMS Microview software was used to analyze $\mu \mathrm{CT}$ data. A threshold of 1100 ADU defined the lower limit for mineralized bone tissue.

Scaffolds used for histological evaluation $(n=12, n=4$ for each microarchitecture) were demineralized with RDO Rapid Decalcifier, sectioned, and stained with hematoxylin and eosin (H\&E). The remaining seeded $(n=30, n=10$ for each microarchitecture) and control $(n=24, n=8$ for each microarchitecture) scaffolds were mechanically tested in compression as described previously. The control scaffolds served as controls for histology and mechanical testing.

\section{Statistical analysis}

Data are expressed as mean \pm standard deviation for each parameter. SPSS 15.0.1 (SPSS, Chicago, IL) was used to perform one-way ANOVA and independent sample ttests. A $p$-value $<0.05$ was considered significant.

\section{RESULTS}

Table II defines the $\mu \mathrm{CT}$ and mechanical testing parameters evaluated in this study. We assessed (1) the effect of scaffold pore size on bone regeneration and mechanical properties, (2) the effect of cells on scaffold mechanical properties, and (3) the effect of 
TABLE II

Definition of Variables Measured with $\mu \mathrm{CT}$ and Mechanical Testing

\begin{tabular}{|c|c|}
\hline Parameters & Definition \\
\hline \multicolumn{2}{|l|}{$\mu \mathrm{CT}$ Parameters } \\
\hline Scaffold volume fraction & Percentage of the scaffold that contains PCL \\
\hline Scaffold porosity & Percentage of scaffold void space \\
\hline Total bone volume & $\begin{array}{l}\text { Volume of mineralized tissue that grew within the scaffold pore space and } \\
\text { outside of the scaffold }\end{array}$ \\
\hline Scaffold bone volume & Volume of mineralized tissue that grew within the scaffold pore space \\
\hline Total bone mineral density (BMD) & $\begin{array}{l}\text { BMD of mineralized tissue that grew within the scaffold pore space and } \\
\text { outside of the scaffold }\end{array}$ \\
\hline Scaffold bone mineral density (BMD) & BMD of the mineralized tissue that grew within the scaffold pore space \\
\hline Scaffold bone volume fraction (BVF) & Percentage of the scaffold pore space filled with mineralized tissue \\
\hline \multicolumn{2}{|l|}{ Mechanical Testing Parameters } \\
\hline Modulus & Compressive Young's modulus \\
\hline Peak stress & Peak stress achieved during compressive loading \\
\hline
\end{tabular}

scaffold implantation time on bone regeneration and scaffold mechanical properties.

\section{Effect of scaffold pore size on bone regeneration and mechanical properties}

Bone grew inside the pore space and formed a cortical shell around the exterior of all seeded scaffolds. Figure 3 shows H\&E staining of bone within the pores of seeded scaffolds 4 and 8 weeks after implantation. Figure $4 \mathrm{a}$ shows a $\mu \mathrm{CT}$ rendering of a $550-\mu \mathrm{m}$ seeded scaffold implanted for 4 weeks surrounded by bone. Figure 4(b) shows a $\mu \mathrm{CT}$ cross-section of a $550-\mu \mathrm{m}$ seeded scaffold implanted for 4 weeks. The scaffold/bone construct can be viewed from the $x-, y-$, and $z$-directions, and bone is visible within the pores and outside the scaffold. BMD of tissue formed after 4 and 8 weeks in vivo was within the normal range of those for human trabecular and cortical bone, $120-1100 \mathrm{mg} / \mathrm{cm}^{3}$, respectively. ${ }^{29}$ Compressive modulus of the scaffold/bone construct was within the lower range of normal human trabecular bone. ${ }^{30}$

The majority of new bone formed outside the scaffold, but some mineralized tissue grew within the scaffold pores as well (Table III). After 4 weeks, scaffold bone volume was significantly greater in $800-\mu \mathrm{m}$ scaffolds than in $350-\mu \mathrm{m}$ scaffolds. Also, modulus and peak stress in $350-\mu \mathrm{m}$ scaffolds were significantly greater than in $550-$ and $800-\mu \mathrm{m}$ scaffolds. After 8 weeks, there were no statistical differ-

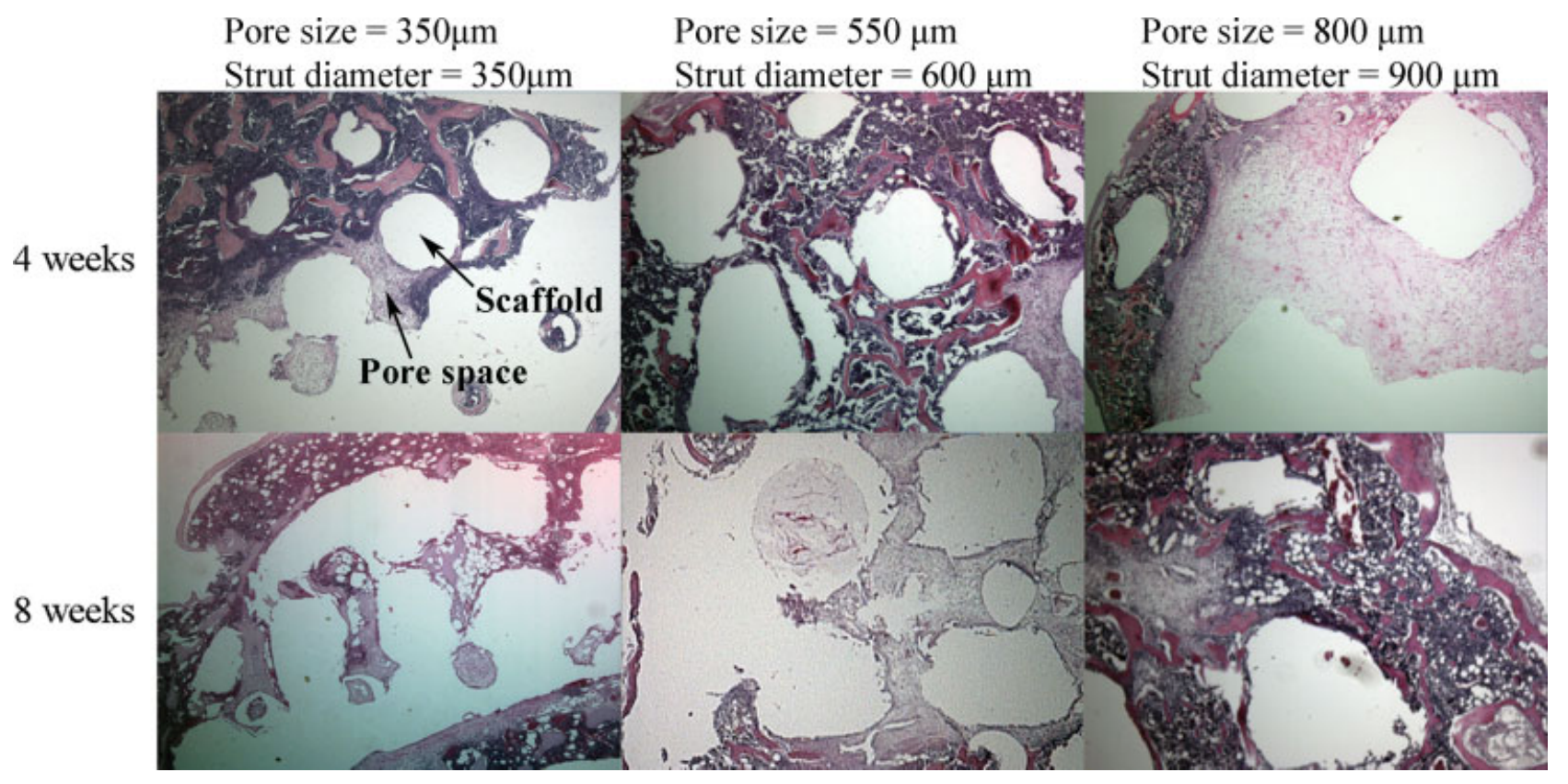

Figure 3. H\&E staining of seeded scaffolds of each microarchitecture 4 and 8 weeks after implantation. Pore space (filled with tissue) and scaffold are labeled in the upper left image, and labeling applies similarly to all images. Magnification for all images is $\times 5$. [Color figure can be viewed in the online issue, which is available at www.interscience.wiley.com.] 

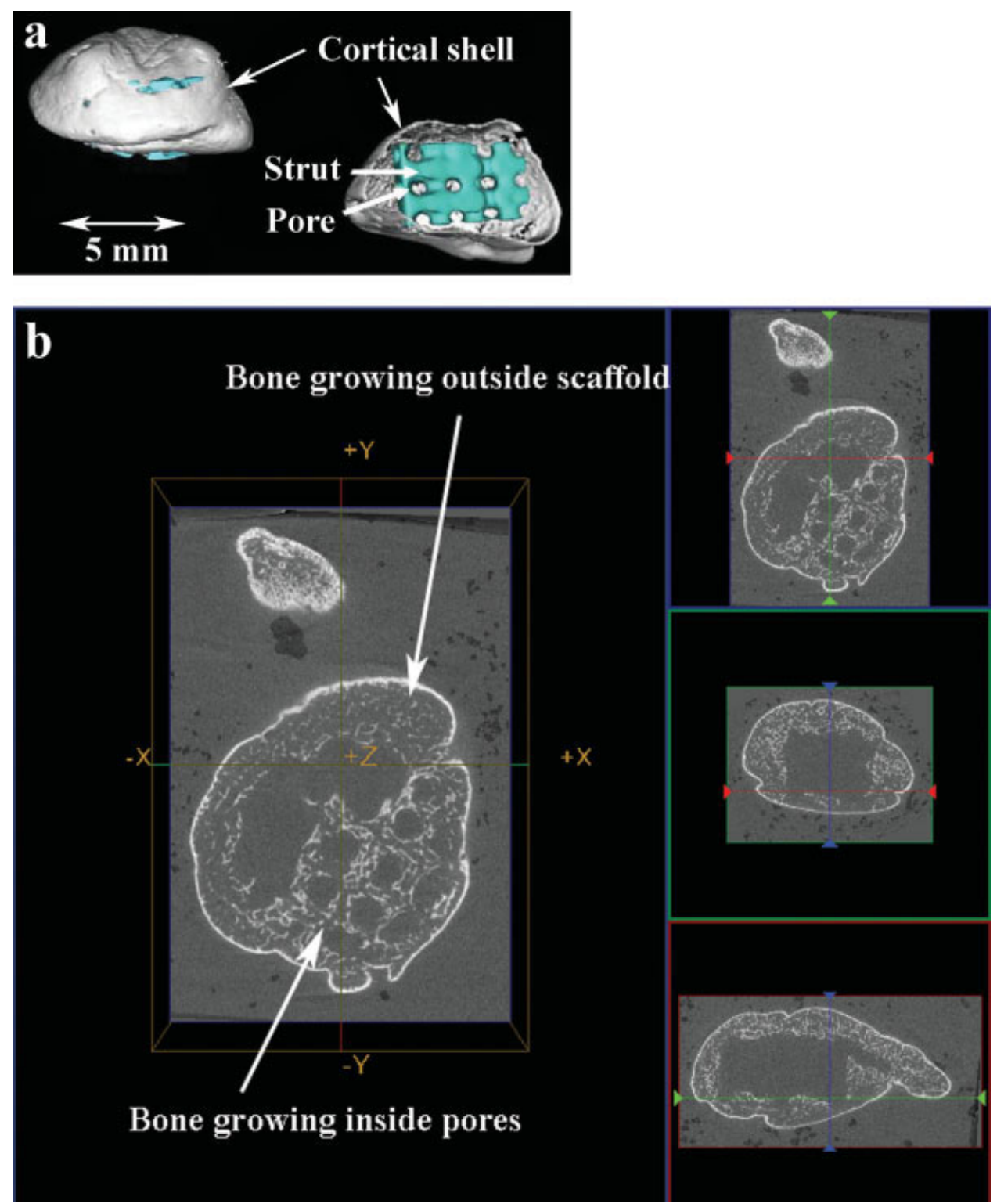

Figure 4. (a) $\mu \mathrm{CT}$ rendering of a 550- $\mu \mathrm{m}$ seeded scaffold 4 weeks after implantation. The majority of new bone (white) grew outside the scaffold (green) and formed a cortical shell. (b) $\mu$ CT cross-section of a 550- $\mu$ m seeded scaffold 4 weeks after implantation. Bone is seen within the scaffold pores and outside the scaffold. [Color figure can be viewed in the online issue, which is available at www.interscience.wiley.com.]

ences between the three architectures in either the amount of bone formed or mechanical properties. It is important to note that scaffold porosity varied for each scaffold microarchitecture. Thus, scaffold porosity may have affected the results (see Discussion section).

Pore size did not affect bulk mechanical properties of mechanical testing scaffolds. Modulus of 350, 550, and $800 \mu \mathrm{m}$ mechanical testing scaffolds was 315.09 $\pm 49.77,246.33 \pm 43.72$, and $298.61 \pm 30.80 \mathrm{MPa}$, respectively. Peak stress of 350, 550, and $800 \mu \mathrm{m}$ mechanical testing scaffolds was $7.07 \pm 5.34,3.40 \pm$ 3.01 , and $6.30 \pm 3.32 \mathrm{MPa}$, respectively. The peak stress of mechanical testing scaffolds was similar to the peak stress in seeded and control subcutaneous scaffolds. The modulus and peak stress of solid PCL cylinders were $645.88 \pm 56.44$ and $14.33 \pm 7.34 \mathrm{MPa}$, respectively.

\section{Effect of cells on scaffold mechanical properties}

Table IV shows the effect of cells on scaffold mechanical properties after 4 and 8 weeks of implantation. At 4 weeks, the modulus of 550 and $800 \mu \mathrm{m}$ seeded scaffolds was significantly decreased compared to control scaffolds. At 8 weeks, the modulus of $550 \mu \mathrm{m}$ seeded scaffolds was significantly decreased compared to control scaffolds. 
TABLE III

Effect of Pore Size on Bone Regeneration and Mechanical Properties in Seeded Scaffolds

\begin{tabular}{|c|c|c|c|}
\hline & \multicolumn{3}{|c|}{ Pore size $(\mu \mathrm{m})$} \\
\hline & 350 & 550 & 800 \\
\hline \multicolumn{4}{|l|}{4 weeks } \\
\hline Total bone volume $\left(\mathrm{mm}^{3}\right)$ & $10.66 \pm 4.67$ & $19.12 \pm 16.94$ & $21.05 \pm 12.78$ \\
\hline Scaffold bone volume ${ }^{\mathrm{a}}\left(\mathrm{mm}^{3}\right)$ & $1.20 \pm 0.46^{\mathrm{b}}$ & $1.64 \pm 0.51$ & $2.24 \pm 0.57^{\mathrm{b}}$ \\
\hline Total BMD $\left(\mathrm{mg} / \mathrm{cm}^{3}\right)$ & $511.23 \pm 36.49$ & $511.78 \pm 31.97$ & $502.98 \pm 18.95$ \\
\hline Scaffold BMD $\left(\mathrm{mg} / \mathrm{cm}^{3}\right)$ & $477.63 \pm 26.95$ & $492.44 \pm 44.74$ & $479.63 \pm 24.67$ \\
\hline Scaffold BVF $(\%)$ & $6.24 \pm 2.7$ & $6.48 \pm 2.1$ & $7.96 \pm 2.5$ \\
\hline Modulus $(\mathrm{MPa})^{\mathrm{a}}$ & $60.18 \pm 4.33^{\mathrm{b}, \mathrm{c}}$ & $32.72 \pm 12.56^{\mathrm{b}}$ & $26.92 \pm 6.15^{\mathrm{c}}$ \\
\hline Peak stress $(\mathrm{MPa})^{\mathrm{a}}$ & $13.54 \pm 3.11^{\mathrm{b}, \mathrm{c}}$ & $7.08 \pm 3.17^{\mathrm{b}}$ & $6.92 \pm 2.32^{c}$ \\
\hline \multicolumn{4}{|l|}{8 weeks } \\
\hline Total bone volume $\left(\mathrm{mm}^{3}\right)$ & $16.14 \pm 8.13$ & $13.78 \pm 5.15$ & $14.75 \pm 5.26$ \\
\hline Scaffold bone volume $\left(\mathrm{mm}^{3}\right)$ & $2.13 \pm 1.56$ & $2.21 \pm 1.05$ & $2.09 \pm 0.61$ \\
\hline Total BMD (mg/ $\left.\mathrm{cm}^{3}\right)$ & $545.76 \pm 26.43$ & $548.42 \pm 22.65$ & $561.96 \pm 33.86$ \\
\hline Scaffold BMD $\left(\mathrm{mg} / \mathrm{cm}^{3}\right)$ & $498.34 \pm 28.88$ & $506.10 \pm 24.00$ & $493.55 \pm 20.07$ \\
\hline Scaffold BVF (\%) & $10.33 \pm 7.3$ & $8.25 \pm 3.5$ & $7.24 \pm 2.2$ \\
\hline Modulus (MPa) & $41.84 \pm 23.10$ & $28.14 \pm 9.49$ & $58.14 \pm 73.51$ \\
\hline Peak stress $(\mathrm{MPa})$ & $9.42 \pm 4.99$ & $6.94 \pm 5.34$ & $6.82 \pm 6.47$ \\
\hline
\end{tabular}

${ }^{a}$ Data is significantly different between seeded scaffolds with different microarchitectures at either time point $(p<0.05)$.

$\mathrm{b}, \mathrm{c}, \mathrm{d}$ Post hoc analysis identifying significant differences in bone regeneration and mechanical properties between scaffolds with different microarchitectures.

\section{Effect of scaffold implantation time on bone regeneration and mechanical properties}

Table V shows the effect of scaffold implantation time on bone regeneration and mechanical properties in seeded scaffolds. Total BMD for 550- and $800-\mu \mathrm{m}$ seeded scaffolds was significantly increased 8 weeks after implantation compared to 4 weeks. All other parameters were unaffected by scaffold implantation time.

\section{DISCUSSION}

The pore size of a tissue engineering scaffold is thought to influence the quantity and characteristics of newly forming tissue. ${ }^{9}$ However, in our tissue engineering model, pore size had a limited influence on new bone formation and scaffold mechanical properties.

Scaffold porosity may have influenced our results. As we designed our scaffolds to have the same global dimensions but distinct microarchitectures, each scaffold design had a different porosity (Figure 5). After 4 weeks of implantation, the $350 \mu \mathrm{m}$ scaffolds had significantly higher modulus and peak stress than 550 and $800 \mu \mathrm{m}$ scaffolds (Table III). However, the $350 \mu \mathrm{m}$ scaffolds had the lowest porosity (i.e. greatest volume fraction of PCL). The increased mechanical properties of the $350 \mu \mathrm{m}$ scaffolds are likely due to larger PCL volume. However, this trend was not continued after 8 weeks so the effect of porosity is not clear.

Also, doubling the implantation time from 4 to 8 weeks may have allowed increased tissue mineralization. Total BMD was increased 8 weeks after

TABLE IV

Effect of Cells on Scaffold Mechanical Properties 4 and 8 Weeks After Implantation

\begin{tabular}{|c|c|c|c|c|c|c|}
\hline \multirow[b]{3}{*}{ Cells } & \multicolumn{6}{|c|}{ Scaffold Pore Size $(\mu \mathrm{m})$} \\
\hline & \multicolumn{2}{|c|}{350} & \multicolumn{2}{|c|}{550} & \multicolumn{2}{|c|}{800} \\
\hline & $\begin{array}{l}\text { Modulus } \\
(\mathrm{MPa})\end{array}$ & $\begin{array}{c}\text { Peak Stress } \\
(\mathrm{MPa})\end{array}$ & $\begin{array}{l}\text { Modulus }^{\mathrm{a}} \\
\text { (MPa) }\end{array}$ & $\begin{array}{c}\text { Peak Stress } \\
(\mathrm{MPa})\end{array}$ & $\begin{array}{l}\text { Modulus }^{\mathrm{a}} \\
\text { (MPa) }\end{array}$ & $\begin{array}{c}\text { Peak Stress } \\
(\mathrm{MPa})\end{array}$ \\
\hline \multicolumn{7}{|l|}{4 weeks } \\
\hline Seeded (Cells) & $60.18 \pm 4.33$ & $13.54 \pm 3.11$ & $32.72 \pm 12.56$ & $7.08 \pm 3.17$ & $26.92 \pm 6.15$ & $6.92 \pm 2.32$ \\
\hline Control (No Cells) & $61.36 \pm 9.92$ & $13.53 \pm 3.69$ & $60.56 \pm 11.23$ & $9.18 \pm 0.93$ & $45.14 \pm 8.44$ & $10.03 \pm 1.95$ \\
\hline \multicolumn{7}{|l|}{8 weeks } \\
\hline Seeded (Cells) & $41.84 \pm 23.10$ & $9.42 \pm 4.99$ & $28.14 \pm 9.49$ & $6.94 \pm 5.34$ & $58.14 \pm 73.51$ & $6.82 \pm 6.47$ \\
\hline Control (No Cells) & $128.19 \pm 93.35$ & $32.35 \pm 22.00$ & $52.10 \pm 6.00$ & $10.60 \pm 1.82$ & $61.89 \pm 49.91$ & $9.60 \pm 2.21$ \\
\hline
\end{tabular}

${ }^{\mathrm{a}}$ Data is significantly different between seeded (Cells) and control (No Cells) scaffolds at either time point $(p<0.05)$. 
TABLE V

Effect of Scaffold Implantation Time on Bone Regeneration and Mechanical Properties in Seeded Scaffolds

\begin{tabular}{lcc}
\hline & \multicolumn{2}{c}{ Weeks } \\
\cline { 2 - 3 } & \multicolumn{2}{c}{4} \\
& & \\
\hline Scaffold pore size $(350 \mu \mathrm{m})$ & $10.66 \pm 4.67$ & $16.14 \pm 8.13$ \\
Total bone volume $\left(\mathrm{mm}^{3}\right)$ & $1.20 \pm 0.46$ & $2.13 \pm 1.56$ \\
Scaffold bone volume $\left(\mathrm{mm}^{3}\right)$ & $511.23 \pm 36.49$ & $545.86 \pm 26.43$ \\
Total BMD $\left(\mathrm{mg} / \mathrm{cm}^{3}\right)$ & $477.63 \pm 26.95$ & $498.34 \pm 28.88$ \\
Scaffold BMD $\left(\mathrm{mg} / \mathrm{cm}^{3}\right)$ & $6.24 \pm 2.7$ & $10.33 \pm 7.3$ \\
Scaffold BVF $(\%)$ & $60.18 \pm 4.33$ & $41.84 \pm 23.10$ \\
Modulus (MPa) & $13.54 \pm 3.11$ & $9.42 \pm 4.99$ \\
Peak stress $(\mathrm{MPa})$ & & \\
Scaffold pore size $\left(550 \mu \mathrm{mm}^{3}\right)$ & $19.12 \pm 16.94$ & $13.78 \pm 5.15$ \\
Total bone volume $\left(\mathrm{mm}^{3}\right)$ & $1.65 \pm 0.51$ & $2.21 \pm 1.05$ \\
Scaffold bone volume $\left(\mathrm{mm}^{3}\right)$ & $511.78 \pm 31.97$ & $548.42 \pm 22.65$ \\
Total BMD $\left(\mathrm{mg} / \mathrm{cm}^{3}\right)$ & $492.44 \pm 44.74$ & $506.10 \pm 24.00$ \\
Scaffold BMD $\left(\mathrm{mg} / \mathrm{cm}^{3}\right)$ & $6.48 \pm 2.1$ & $8.25 \pm 3.5$ \\
Scaffold BVF $(\%)$ & $32.72 \pm 12.56$ & $28.14 \pm 9.49$ \\
Modulus $(\mathrm{MPa})$ & $7.08 \pm 3.17$ & $6.94 \pm 5.34$ \\
Peak stress $(\mathrm{MPa})$ & & \\
Scaffold pore size $\left(800 \mu \mathrm{mm}^{3}\right)$ & $21.05 \pm 12.78$ & $14.75 \pm 5.26$ \\
Total bone volume $\left(\mathrm{mm}^{3}\right)$ & $2.24 \pm 0.57$ & $2.09 \pm 0.61$ \\
Scaffold bone volume $\left(\mathrm{mm}^{3}\right)$ & $502.98 \pm 18.95$ & $561.96 \pm 33.86$ \\
Total BMD $\left(\mathrm{mg} / \mathrm{cm}^{3}\right)^{\mathrm{a}}$ & $479.63 \pm 24.67$ & $493.55 \pm 20.07$ \\
Scaffold BMD $\left(\mathrm{mg} / \mathrm{cm}^{3}\right)$ & $7.96 \pm 2.5$ & $7.24 \pm 2.2$ \\
Scaffold BVF $(\%)$ & $26.92 \pm 6.15$ & $58.14 \pm 73.51$ \\
Modulus $(\mathrm{MPa})$ & $6.92 \pm 2.32$ & $6.82 \pm 6.47$ \\
Peak stress $(\mathrm{MPa})$ & & \\
\hline
\end{tabular}

${ }^{a}$ Data is significantly different between scaffolds implanted for 4 or 8 weeks for a given pore size $(p<0.05)$.

implantation compared to 4 weeks in 550- and 800$\mu \mathrm{m}$ seeded scaffolds (Table V); however, a corresponding increase in modulus and peak stress was not observed.

The addition of cells decreased scaffold mechanical properties over time. The 550 and $800 \mu \mathrm{m}$ control scaffolds had a higher modulus compared to seeded scaffolds at 4 weeks, and this trend continued for $550 \mu \mathrm{m}$ scaffolds at 8 weeks (Table IV). The seeded scaffold mechanical properties may have decreased if the HGFs induced PCL degradation and consequently scaffold weakening. HGF-induced PCL degradation would likely become more pronounced in scaffolds implanted for time periods longer than 8 weeks, but further study is necessary to determine the extent of PCL degradation in our tissue engineering model.

Control scaffolds maintained mechanical properties after 4 and 8 weeks in vivo. Thus, control scaffolds did not seem to degrade significantly during this time period. However, control scaffolds could degrade if implanted for time periods longer than 8 weeks, as the reported degradation time for PCL scaffolds ranges between 21 days to 2 years. ${ }^{31,32}$ The degradation rate is affected by many parameters, including fabrication technique, scaffold design, implant location, and addition of cells and/or biological factors.

In our tissue engineering model, the majority of bone grew outside the scaffold as observed in previous studies. ${ }^{12,19}$ However, there was some bone ingrowth within the pore space, and this model should be refined to increase the quantity of bone ingrowth. Scaffold bone volume was significantly increased in $800 \mu \mathrm{m}$ scaffolds compared to $350 \mu \mathrm{m}$ scaffolds after 4 weeks of implantation (Table III). After 8 weeks, scaffold bone volume for all scaffold microarchitectures was similar. Together, the results at 4 and 8 weeks suggest that pore sizes between 350 and $800 \mu \mathrm{m}$ in PCL scaffolds have a limited effect on bone regeneration. Similar results were previously demonstrated by Schek et al., ${ }^{19}$ who found that pore sizes of 300 and $800 \mu \mathrm{m}$ did not affect bone regeneration in PPF/ $\beta$-TCP scaffolds.

Bone regeneration in scaffolds with pore sizes smaller than $350 \mu \mathrm{m}$ is variable. In one study, calcium aluminate pellets with pore sizes ranging between 10 and $200 \mu \mathrm{m}$ were implanted into dog femurs. ${ }^{16}$ Pore sizes between 100 and $200 \mu \mathrm{m}$ resulted in bone in-growth, while pore sizes between 10 and $100 \mu \mathrm{m}$ resulted in fibrous tissue or unmineralized osteoid in-growth. ${ }^{16}$ In contrast, when titanium plates with pore sizes of $50,75,100$, or $125 \mu \mathrm{m}$ were implanted into rabbit femurs, no differences in bone in-growth were observed between pore sizes. ${ }^{33}$ A more recent study found that PCL scaffolds with pore sizes between 186 and $200 \mu \mathrm{m}$ were best for fibroblast infiltration, whereas scaffolds with pore sizes between 290 and $310 \mu \mathrm{m}$ showed the fastest bone formation. ${ }^{15}$ Although we found that pore sizes between 350 and $800 \mu \mathrm{m}$ did not affect bone ingrowth, scaffolds with pore sizes smaller than $350 \mu \mathrm{m}$ exhibit varying degrees of bone in-growth. Thus, the influence of smaller pore sizes on bone

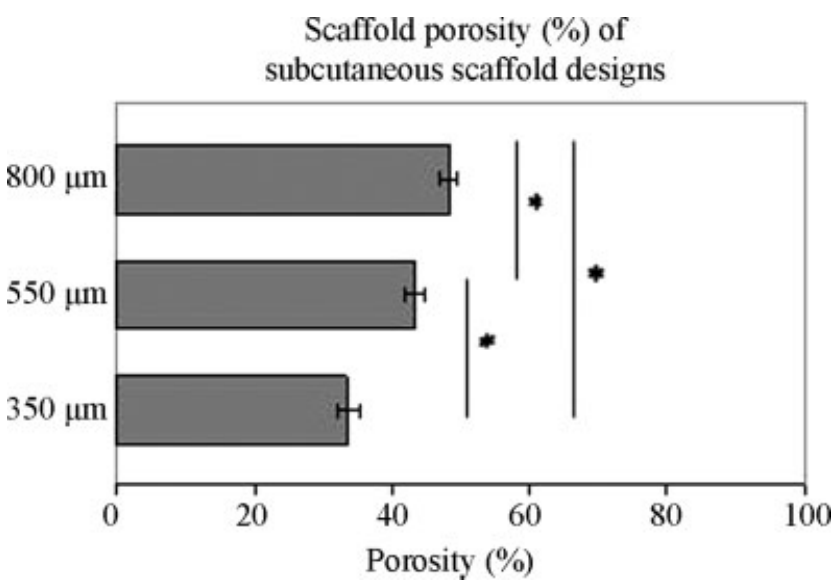

Figure 5. Porosity of 350, 550, and $800 \mu \mathrm{m}$ scaffolds. *Indicates a statistically significant difference in porosity $(p<0.05)$. 
in-growth is unclear, and is likely affected by several factors, including biomaterial, fabrication technique, scaffold design, implant location, and addition of cells and/or biological factors.

We observed a small amount of new bone ingrowth in seeded scaffolds. As we used an ex vivo strategy developed previously in our lab, ${ }^{34}$ we expected to see higher amounts of bone in-growth. A possible reason for the small amount of in-growth is that we implanted scaffolds into subcutaneous pockets. If the scaffolds had been implanted into muscle or an orthotopic site, we may have seen better results. However, our tissue engineering model generated new bone growth in an ectopic site, which suggests that our model is more robust than orthotopic tissue engineering models.

Another possible reason for the small amount of bone in-growth is that we used a rigorous bone threshold of 1100 ADU in our $\mu \mathrm{CT}$ analysis to characterize mineralized bone. Thus, we excluded immature bone that was not completely mineralized after 4 or 8 weeks in vivo. Analysis of scaffolds implanted for longer than 8 weeks may determine if bone ingrowth increases with implantation time.

In conclusion, we found that (1) modulus and peak stress of the scaffold/bone constructs depended on pore size at 4 weeks but not at 8 weeks, (2) bone growth inside pores depended on pore size at 4 weeks but not at 8 weeks, and (3) the length of implantation time had a limited effect on scaffold/bone construct properties. Therefore, pore sizes between 350 and $800 \mu \mathrm{m}$ play a limited role in bone regeneration in this tissue engineering model. It may be advantageous to explore the effects of other scaffold structural properties, such as pore shape, pore interconnectivity, or scaffold permeability, on bone regeneration when designing PCL scaffolds for bone tissue engineering.

The authors thank Alisha Diggs and Colleen Flanagan for help with scaffold fabrication, and Darice Wong, Elly Liao, and John Kemppainen for help with animal surgeries.

\section{References}

1. Campbell GR, Campbell JH. Development of tissue engineered vascular grafts. Curr Pharm Biotechnol 2007;8:43-50.

2. Chalfoun CT, Wirth GA, Evans GR. Tissue engineered nerve constructs: Where do we stand? J Cell Mol Med 2006;10:309317.

3. Clark RA, Ghosh K, Tonnesen MG. Tissue engineering for cutaneous wounds. J Invest Dermatol 2007;127:1018-1029.

4. Hutmacher DW, Schantz JT, Lam CX, Tan KC, Lim TC. State of the art and future directions of scaffold-based bone engineering from a biomaterials perspective. J Tissue Eng Regen Med 2007;1:245-260.
5. Mikos AG, Herring SW, Ochareon P, Elisseeff J, Lu HH, Kandel R, Schoen FJ, Toner M, Mooney D, Atala A, Van Dyke ME, Kaplan D, Vunjak-Novakovic G. Engineering complex tissues. Tissue Eng 2006;12:3307-3339.

6. Vunjak-Novakovic G, Altman G, Horan R, Kaplan DL. Tissue engineering of ligaments. Annu Rev Biomed Eng 2004;6:131156.

7. Hollister SJ, Lin CY, Saito E, Schek RD, Taboas JM, Williams JM, Partee B, Flanagan CL, Diggs A, Wilke EN, Van Lenthe GH, Muller R, Wirtz T, Das S, Feinberg SE, Krebsbach PH. Engineering craniofacial scaffolds. Orthod Craniofac Res 2005;8:162-173.

8. Hutmacher DW, Schantz T, Zein I, Ng KW, Teoh SH, Tan KC. Mechanical properties and cell cultural response of polycaprolactone scaffolds designed and fabricated via fused deposition modeling. J Biomed Mat Res 2001;55:203216.

9. Karageorgiou V, Kaplan D. Porosity of 3D biomaterial scaffolds and osteogenesis. Biomaterials 2005;26:5474-5491.

10. Lee SJ, Lee IW, Lee YM, Lee HB, Khang G. Macroporous biodegradable natural/synthetic hybrid scaffolds as small intestine submucosa impregnated poly(D,L-lactide-co-glycolide) for tissue-engineered bone. J Biomater Sci Polym Ed 2004;15: 1003-1017.

11. Lin C-Y, Schek RM, Mistry AS, Shi X, Mikos AG, Krebsbach $\mathrm{PH}$, Hollister SJ. Functional bone engineering using ex vivo gene therapy and topology-optimized. Biodegradable polymer composite scaffolds. Tissue Eng 2005;11:1589-1598.

12. Williams JM, Adewunmi A, Schek RM, Flanagan CL, Krebsbach PH, Feinberg SE, Hollister SJ, Das S. Bone tissue engineering using polycaprolactone scaffolds fabricated via selective laser sintering. Biomaterials 2005;26:4817-4827.

13. Shor L, Guceri S, Wen X, Gandhi M, Sun W. Fabrication of three-dimensional polycaprolactone/hydroxyapatite tissue scaffolds and osteoblast-scaffold interactions in vitro. Biomaterials 2007;28:5291-5297.

14. Zhang R, Ma PX. Poly( $\alpha$-hydroxyl acids)/hydroxyapatite porous composites for bone-tissue engineering. I. Preparation and morphology. J Biomed Mater Res 1999;44:446-455.

15. Oh SH, Park IK, Kim JM, Lee JH. In vitro and in vivo characteristics of PCL scaffolds with pore size gradient fabricated by a centrifugation method. Biomaterials 2007;28:16641671.

16. Hulbert SF, Young FA, Mathews RS, Klawitter JJ, Talbert CD, Stelling FH. Potential of ceramic materials as permanently implantable skeletal prostheses. J Biomed Mater Res 1970;4: 433-456.

17. Cyster L, Grant D, Howdle S, Rose F, Irvine D, Freeman D, Scotchford C, Shakesheff K. The influence of dispersant concentration on the pore morphology of hydroxyapatite ceramics for bone tissue engineering. Biomaterials 2005;26: 697-702.

18. Schek RM, Taboas JM, Hollister SJ, Krebsbach PH. Tissue engineering osteochondral implants for temporomandibular joint repair. Orthod Craniofac Res 2005;8:313-319.

19. Schek RM, Wilke EN, Hollister SJ, Krebsbach PH. Combined use of designed scaffolds and adenoviral gene therapy for skeletal tissue engineering. Biomaterials 2006;27:1160-1166.

20. Rohner D, Hutmacher DW, Cheng TK, Oberholzer M, Hammer B. In vivo efficacy of bone-marrow-coated polycaprolactone scaffolds for the reconstruction of orbital defects in the pig. J Biomed Mater Res B Appl Biomater 2003;66:574580.

21. Causa F, Netti PA, Ambrosio L, Ciapetti G, Baldini N, Pagani S, Martini D, Giunti A. Poly-epsilon-caprolactone/hydroxyapatite composites for bone regeneration: In vitro characterization and human osteoblast response. J Biomed Mater Res A 2006;76:151-162. 
22. Savarino L, Baldini N, Greco M, Capitani O, Pinna S, Valentini S, Lombardo B, Esposito MT, Pastore L, Ambrosio L, Battista S, Causa F, Zeppetelli S, Guarino V, Netti PA. The performance of poly-epsilon-caprolactone scaffolds in a rabbit femur model with and without autologous stromal cells and BMP4. Biomaterials 2007;28:3101-3109.

23. Venugopal J, Low S, Choon AT, Kumar AB, Ramakrishna S. Electrospun-modified nanofibrous scaffolds for the mineralization of osteoblast cells. J Biomed Mater Res A 2008;85:408-417.

24. Izquierdo R, Garcia-Giralt N, Rodriguez MT, Caceres E, Garcia SJ, Gomez Ribelles JL, Monleon M, Monllau JC, Suay J. Biodegradable PCL scaffolds with an interconnected spherical pore network for tissue engineering. J Biomed Mater Res A 2008;85:25-35.

25. Li WJ, Danielson KG, Alexander PG, Tuan RS. Biological response of chondrocytes cultured in three-dimensional nanofibrous poly(epsilon-caprolactone) scaffolds. J Biomed Mater Res A 2003;67:1105-1114.

26. Li WJ, Tuli R, Okafor C, Derfoul A, Danielson KG, Hall DJ, Tuan RS. A three-dimensional nanofibrous scaffold for cartilage tissue engineering using human mesenchymal stem cells. Biomaterials 2005;26:599-609.

27. Swieszkowski W, Tuan BH, Kurzydlowski KJ, Hutmacher DW. Repair and regeneration of osteochondral defects in the articular joints. Biomol Eng 2007;24:489-495.
28. Taboas JM, Maddox RD, Krebsbach PH, Hollister SJ. Indirect solid free form fabrication of local and global porous, biomimetic and composite 3D polymer-ceramic scaffolds. Biomaterials 2003;24:181-194.

29. Chen Q, Kaji H, Iu M, Nomura R, Sowa H, Yamauchi M, Tsukamoto T, Sugimoto T, Chihara K. Effects of an excess and a deficiency of endogenous parathyroid hormone on volumetric bone mineral density and bone geometry determined by peripheral quantitative computed tomography in female subjects. J Clin Endocrinol Metab 2003;88:4655-4658.

30. Goulet R, Goldstein S, Ciarelli M, Kuhn J, Brown M, Feldkamp L. The relationship between the structural and orthogonal compressive properties of trabecular bone. J Biomech 1994;27:375-389.

31. Hutmacher DW. Scaffolds in tissue engineering bone and cartilage. Biomaterials 2000;21:2529-2543.

32. Sung HJ, Meredith C, Johnson C, Galis ZS. The effect of scaffold degradation rate on three-dimensional cell growth and angiogenesis. Biomaterials 2004;25:5735-5742.

33. Itala AI, Ylanen HO, Ekholm C, Karlsson KH, Aro HT. Pore diameter of more than 100 microm is not requisite for bone ingrowth in rabbits. J Biomed Mater Res 2001;58:679-683.

34. Schek RM, Hollister SJ, Krebsbach PH. Delivery and protection of adenoviruses using biocompatible hydrogels for localized gene therapy. Mol Ther 2004;9:130-138. 